Тетяна ШИНКАР,

orcid.org/0000-0002-5656-2032

викладач кафедри дошкільної освіти

Педагогічного інституту Київького університету імені Бориса Грінченка

(Київ, Украӥна) t.shynkar@kubg.edu.ua

\title{
МЕТОДИЧНА РОБОТА В ЗАКЛАДАХ ДОШКІЛЬНОЇ ОСВІТИ: НОРМАТИВНО-ПРАВОВІ АСПЕКТИ
}

\begin{abstract}
У статті розглянуто особливості організації методичної роботи в закладах дошкільної освіти на сучасному етаni. З'ясовано, шуо одним зі шляхів реформування дошкільної освіти є якісна організачія методичної роботи, яка є показником успішності діяльності закладу дошкільної освіти. Методична робота в закладі дошкільної освіти - багатоаспектне поняття, що передбачає: вивчення та моделювання освітнього прочесу; супровід професійної компетентності педагогів, підвищення їхньої педагогічної майстерності; вивчення динаміки змін у розвитку дошкільників; консультативну допомогу педагогам; організацію партнерської взаємодії з батьками; вивчення, узагальнення та поширення перспективного педагогічного досвіду; створення сприятливого психологічного клімату в педагогічному колективі; добір та опрацювання методичної, наукової літератури тощзо. Тому питання нормативно-правового забезпечення виступає першочерговим в організації методичної роботи в закладі дошкільної освіти.

Розкрито зміст та особливості використання основних законодавчих, нормативних та відомчих документів. Визначено, щь відповідно до державної освітньої політики формуються нові підходи до організації методичної роботи в закладах дошкільної освіти. Методична робота в закладах дошкільної освіти регламентується низкою нормативно-правових документів. Розглянуті основні, законодавчі, нормативні та відомчі документи, а саме: Державна начіональна програма «Освіта» («Украӥна ХХІ століття»), Закони Украӥни «Про освіту», «Про доикільну освіту», Наказ «Про затвердження кваліфікаиійних характеристик професій (посад) педагогічних та науково-педагогічних працівників навчальних закладів», Примірне положення про методичний кабінет закладу дошкільної освіти, Постанова Кабінету Міністрів України «Деякі питання підвищення кваліфікації педагогічних і науково-педагогічних працівників», Інструктивно-методичні рекомендації «Щодо організації діяльності закладів освіти, щзо забезпечують здобуття дошкільної освіти у 2019/2020 навчальному році».
\end{abstract}

Ключові слова: заклад дошкільної освіти, методична робота, методичний кабінет, вихователь-методист, науково-методичне забезпечення.

Tetiana SHYNKAR, orcid.org/0000-0002-5656-2032

Teacher at the Department of Preschool Education of Pedagogical Institute of Boris Grinchenko Kyiv University (Kyiv,Ukraine) t.shynkar@kubg.edu.ua

\section{METHODICAL WORK IN PRESCHOOL EDUCATIONAL INSTITUTIONS: REGULATORY AND LEGAL ASPECTS}

The article deals with the peculiarities of the organization of methodical work in preschool educational institutions at the present stage. It has been found out that one of the ways of reforming preschool education is qualitative organization of methodical work, which is an indicator of successful activity of preschool educational institution. Methodical work in the preschool educational institution is a multidimensional concept, which includes: studying and modeling of the educational process; support of teachers' professional competence, improvement of their pedagogical skills; studying the dynamics of changes in the development of preschool children; advisory assistance to teachers; organizing partnerships with parents; study, generalization and dissemination of perspective pedagogical experience; creation of a favorable psychological climate in the teaching staff; selection and working with methodological, scientific literature, etc. Therefore, the issue of regulatory and legal support is of paramount importance in organizing of methodical work in preschool educational institution.

The content and peculiarities of using the main legislative, regulatory and departmental documents are disclosed. It is determined that, in accordance with the state educational policy, new approaches to the organization of methodical work in preschool educational institutions are being formed. Methodical work in preschool educational institutions is regulated by a number of regulatory and legal documents. The basic, legislative, normative and departmental documents are considered, namely: State National Program "Education" ("Ukraine of the 21st Century”), Laws of Ukraine "On Education”, "On Preschool Education", Order "On approval of qualification characteristics of professions (posts) of pedagogical and scientific-pedagogical employees of educational institutions", Exemplary Regulation on the Methodological Office of the Preschool Educational Institution, Resolution of the Cabinet of Ministers of Ukraine "Some Issues of Training of Pedagogical and Scientific-Pedagogical Workers", Instructional and methodical recommendations "On the organization of activities of educational institutions providing preschool education in the 2019/2020 school year".

Key words: preschool educational institution, methodical work, methodological office, methodologist, methodological support. 
Постановка проблеми. В умовах реформування освіти виникає потреба зміни підходів до організації методичної роботи загалом й організації науковометодичного супроводу професійної діяльності педагогів зокрема. Очевидно, що має відбутися конструктивний і аналітичний перегляд основоположних підходів, концепцій, позицій і стратегій щодо ролі, основних завдань і функцій методичної роботи закладів дошкільної освіти. Перш ніж визначити ефективні кроки на шляху до перебудови організації методичної роботи, необхідно проаналізувати діючу нормативну правову базу організації методичної роботи в закладах дошкільної освіти. Тому порушену проблематику вважаємо актуальною.

Аналіз досліджень. Загальні теоретичні аспекти методичної роботи в закладах освіти різного рівня висвітлено в працях I. Жерносєка, В. Колібабчука, С. Майданенко, В. Павленко та ін. Науковці Г. Бєлєнька, К. Біла, О. Долинна, I. Жерносєк, О. Корнєєва, В. Крижко, К. Крутій, А. Морозова, Н. Омельяненко, Н. Савінова, В. Семізорова, Л. Швайка, О. Янко та ін. у своїх працях розкривають зміст, форми, особливості організації методичної роботи в сучасних закладах дошкільної освіти. Генеза організації методичної роботи в радянській і вітчизняній освіті розглянуто в працях В. Дородних, А. Срмоли, Л. Калініної, Г. Литвиненка, Ю. Сирової, Т. Ткачевої та ін.

Належної уваги потребує аналіз періодичних видань, зокрема: щомісячний, єдиний в Україні, спеціалізований журнал для вихователів-методистів закладів дошкільної освіти «Вихователь-методист дошкільного закладу»; журнал «Методична скарбничка вихователя»; спеціалізований журнал для керівника закладу дошкільної освіти «Практика управління дошкільним закладом»; журнал «Дошкільне виховання»; журнал «Палітра педагога»; газета «Дитячий садок». Зазначені часописи слугують орієнтиром в методичній роботі закладу дошкільної освіти, розкривають основні аспекти роботи методичного кабінету, містять рекомендації, відповіді на важливі запитання, інструментарій для роботи $з$ дітьми, а також активно впливають на формування науково-педагогічної свідомості педагогів, підтримують розвиток інноваційних технологій та поширюють перспективний досвід освітян. Дописувачі - досвідчені, інноваційні педагоги-практики та авторитетні науковці в царині дошкільної освіти України, зокрема Г. Бєлєнька, А. Богуш, Н. Гавриш, К. Крутій, С. Ладивір, Т. Піроженко та ін.

Мета статті - розкрити зміст та особливості використання основних законодавчих, нормативних та відомчих документів, що регламентують процес організації методичної роботи в закладах дошкільної освіти.

Виклад основного матеріалу. Методична робота $\epsilon$ багатоаспектним поняттям і передбачає виконання низки важливих завдань у закладі дошкільної освіти: систематичне вивчення стану освітнього процесу, професійної компетентності педагогів, динаміки змін у розвитку здобувачів дошкільної освіти; консультування та допомога педагогам щодо планування освітнього процесу 3 дітьми; організація співпраці з батьками; моделювання змісту, форм та методів освітнього процесу; підвищення педагогічної майстерності та вдосконалення професійної компетентності педагогів; вивчення, узагальнення та поширення перспективного педагогічного досвіду; створення сприятливого психологічного клімату в педагогічному колективі; добір та опрацювання методичної, наукової літератури та надання рекомендацій щодо іії впровадження в освітній процес закладу дошкільної освіти тощо. Тому питання нормативно-правового забезпечення виступає першочерговим в організації методичної роботи в закладі дошкільної освіти.

Л. Швайка в посібнику для вихователів-методистів, керівників, педагогів закладів дошкільної освіти розглядає теоретичний складник основних засад методичної роботи та зразки необхідного практичного матеріалу організації методичної роботи з педагогами, освітнього процесу, контрольно-аналітичної діяльності та ін. Також автором представлено перелік основних нормативних документів, що мають зберігатися в методичному кабінеті закладу дошкільної освіти. Автор поділяє їх на: базові; установчі; документи з атестації; документи 3 діловодства; обладнання; документи 3 планування; документи психологічної служби; документи з охорони життя і здоров'я; документи щодо роботи 3 дітьми, що не відвідують заклад дошкільної освіти; документи, щодо роботи 3 батьками; документи 3 фізичного виховання (Швайка Л., 2017: 6-11).

Ми ж розглянемо основні законодавчі, нормативні та відомчі документи, що регламентують процес організації методичної роботи в закладах дошкільної освіти.

Методична робота $є$ важливим показником успішності роботи закладу дошкільної освіти та одним з основних шляхів реформування освіти, визначеним Державною національною програмою «Освіта» («Україна XXI століття»), Законами України «Про освіту», «Про дошкільну освіту», Базовим компонентом дошкільної освіти та ін.

У Державній національній програмі «Освіта» («Україна XXI століття») зазначено, що забез- 
печення розвитку освіти здійснюється на основі нових прогресивних концепцій, запровадження в освітній процес сучасних педагогічних технологій та науково-методичних досягнень. Серед основних шляхів реформування дошкільної освіти визначено створення оптимальних науково-методичних, організаційно-педагогічних, санітарно-гігієнічних, матеріально-технічних, естетичних умов функціонування дошкільних установ різних типів і профілів (Законодавство України: [сайт] URL: https:// zakon.rada.gov.ua/laws/show/896-93-\%D0\%BF)

Закон України «Про освіту» кожному закладу освіти надає організаційну, кадрову, академічну автономію. Педагогічний колектив, а особливо директор та вихователь-методист, повністю відповідальні за процес та результат освітнього процесу закладу дошкільної освіти та методичної роботи зокрема (Законодавство України: [сайт] URL: https://zakon.rada.gov.ua/laws/show/2145-19).

У Законі України «Про дошкільну освіту» визначено завдання науково-методичного забезпечення системи дошкільної освіти, а саме:

- розроблення та впровадження програмнометодичної бази дошкільної освіти;

- створення освітніх програм, навчальнометодичних та навчально-наочних посібників;

- узагальнення та поширення передового педагогічного досвіду;

- організація співпраці 3 іншими навчальними закладами для підвищення ефективності програмно-методичного забезпечення;

- аналіз стану освітньої роботи й рівня розвитку дитини відповідно до завдань дошкільної освіти, Базового компонента дошкільної освіти;

- підготовка, перепідготовка та підвищення кваліфікації педагогічних працівників системи дошкільної освіти;

- пропаганда просвітницької діяльності в засобах масової інформації (Законодавство України: [сайт] URL: https://zakon.rada.gov.ua/laws/ main/2628-14).

У Статті 25, зазначено, що науково-методичне забезпечення системи дошкільної освіти здійснюють:

- центральний орган виконавчої влади, що реалізує державну політику у сфері освіти, підпорядковані йому науково-методичні установи та вищі педагогічні навчальні заклади, а також науково-дослідні установи Національної академії педагогічних наук України та Національної академії наук України;

- Центральний інститут післядипломної педагогічної освіти Національної академії педагогічних наук України;
- методичні кабінети та інші науково-методичні установи, що підпорядковані місцевим органам управління освітою (Законодавство України: [сайт] URL: https://zakon.rada.gov.ua/ laws/main/2628-14).

Методичну роботу в закладі дошкільної освіти здійснює вихователь-методист. У закладах дошкільної освіти, де посада вихователя-методиста не передбачена, методичною роботою опікується директор закладу.

У посадових обов'язках вихователя-методиста закладу дошкільної освіти передбачено, що вихователь-методист: відповідає за організацію освітнього процесу; здійснює методичне керівництво освітньою діяльністю педагогічного колективу дошкільного закладу; створює умови для забезпечення фізичного та психічного розвитку дітей, впроваджує особистісно-орієнтований та компетентністний підходи в практику роботи; сприяє реалізації диференційованого підходу до вихованців, виявленню їхніх індивідуальних особливостей, здібностей, таланту, виконанню правил охорони праці та безпеки життєдіяльності; організовує наставництво молодих спеціалістів, надає допомогу студентам педагогічних вузів у проходженні практики; здійснює роботу з батьками 3 питань розвитку, виховання та навчання дітей; здійснює систематичний контроль за якістю педагогічного процесу в закладі; допомагає створити сприятливий емоційно-психологічний клімат у педагогічному колективі тощо (Освіта иа. [сайт] URL: https:/osvita.ua/legislation/other/37302/).

Центром методичної роботи в закладі дошкільної освіти є методичний кабінет. Робота методичного кабінету регламентується Примірним положенням про методичний кабінет закладу дошкільної освіти (Міністерство освіти і науки України. [сайт] URL: https://mon.gov.ua/ua/npa/ pro-zatverdzhennya-primirnogo-polozhennya-prometodichnij-kabinet-zakladu-doshkilnoyi-osviti).

Метою роботи методичного кабінету є: надання методичної допомоги педагогічним працівникам щодо їх професійного розвитку, підвищення кваліфікації, професійної компетентності; підготовка та проведення освітнього процесу 3 дітьми, роботи з батьками вихованців; навчально-методичне забезпечення освітнього процесу в закладі дошкільної освіти; поширення серед батьків психолого-педагогічних знань; створення сприятливих умов для самовдосконалення педагогів, розвитку творчої ініціативи у них; забезпечення методичної підтримки щодо реалізації педагогічних ініціатив та апробації навчальної літератури, методичних розробок тощо. 
Відповідно до Положення діяльність методичного кабінету грунтується на принципах демократизму і гуманізму, відкритості, системного підходу до методичного та інформаційно-аналітичного супроводу діяльності закладу дошкільної освіти, рівності умов для кожного педагогічного працівника щодо повної реалізації його духовного, творчого та інтелектуального потенціалу; безперервності професійного вдосконалення; науковості, гнучкості та прогностичності методичної роботи з педагогічними кадрами.

Функції методичного кабінету полягають y: врахуванні можливостей розвитку дошкільної освіти та особливостей діяльності закладу дошкільної освіти; використанні сучасних наукових досягнень; інформуванні педагогів про інновації в галузі дошкільної освіти та використання їх у практичній діяльності; розробленні методичних рекомендацій, зразків дидактичних посібників дидактичних ігор та вправ; наданні консультацій та практичної допомоги педагогам і батькам дітей дошкільного віку; моніторингу освітнього процесу, динаміки змін у розвитку дітей, професійної компетентності педагогічних працівників; моделюванні змісту, форм і методів підвищення фахової кваліфікації педагогів; виявленні, вивченні, узагальненні та поширенні перспективного педагогічного досвіду; створенні позитивного психологічного клімату в закладі дошкільної освіти тощо.

Наповнюваність методичного кабінету повинна відповідати вимогам: інформативності та змістовності; доступності; сучасності; естетичності; задовольняти потреби педагогів у саморозвитку і самовдосконаленні. У методичному кабінеті має бути створено електронний інформаційний банк.

Методичний кабінет закладу дошкільної освіти $€$ координатором методичної допомоги педагогічним працівникам закладу дошкільної освіти та поширення серед батьків психолога-педагогічних знань щодо забезпечення цілісного розвитку дитини, iï фізичних, інтелектуальних і творчих здібностей шляхом виховання, навчання, соціалізації та формування необхідних життєвих навичок (Міністерство освіти і науки України. [сайт] URL: https://mon.gov.ua/ua/npa/pro-zatverdzhennyaprimirnogo-polozhennya-pro-metodichnij-kabinetzakladu-doshkilnoyi-osviti).

Одним зі складників методичної роботи в закладі дошкільної освіти є підвищення кваліфікації педагогічних працівників. Підвищення кваліфікації педагогічних працівників закладів дошкільної освіти регламентується Постановою
Кабінету Міністрів України «Деякі питання підвищення кваліфікації педагогічних і науковопедагогічних працівників» № 800 від 21 серпня 2019 року. Педагогічні працівники закладів дошкільної освіти мають підвищувати свою кваліфікацію не рідше одного разу на п'ять років. Загальний обсяг підвищення кваліфікації педагогічного працівника закладу дошкільної освіти не може бути менше ніж 120 годин на п’ять років. Підвищення кваліфікації може здійснюватися шляхом інформальної освіти (самоосвіти) - ще однієї складової частини методичної роботи в закладі дошкільної освіти. У такому разі замість документа про підвищення кваліфікації подається звіт про результати підвищення кваліфікації та оприлюднюється на веб-сайті закладу та/ або в електронному портфоліо педагогічного працівника (у разі наявності). Форму звіту визначає заклад дошкільної освіти (Законодавство України: [сайт] URL: https://zakon.rada.gov.ua/laws/ show/800-2019-\%D0\%BF).

Розглянемо ще один документ в організації освітнього процесу закладу дошкільної освіти та методичної роботи - Лист МОН № 1/9-419 від 02.07.19 року «Щодо організації діяльності закладів освіти, що забезпечують здобуття дошкільної освіти у 2019/2020 навчальному році» (Міністерство освіти і науки України: [сайт] URL: https:// mon.gov.ua/ua/npa/shodo-organizaciyi-diyalnostizakladiv-osviti-sho-zabezpechuyut-zdobuttyadoshkilnoyi-osviti-u-20192020-navchalnomu-roci). У документі підняті такі важливі питання, як вибір освітньої програми в закладі дошкільної освіти, організація освітнього процесу, особливості діяльності інклюзивних груп, організація предметно-просторового розвивального середовища, планування освітньої роботи, особливості підвищення кваліфікації педагогів, підвищення професійної майстерності, партнерська взаємодія 3 батьками вихованців. У листі представлено досвід організації методичної роботи методичних кабінетів та колективів закладів дошкільної освіти міст Миколаєва та Херсона. В основі методичної служби - векторність і адресна спрямованість науково-методичного супроводу професійного розвитку педагогів, який змодельовано залежно від індивідуальних запитів, потреб, мотивації педагогів, їхніх професійних можливостей, наявного досвіду - соціального, професійного й особистісного. Наведено приклади дієвих форм методичної роботи, як-то: Ресурсний центр, Методичний дайджест, авторська Школа інноваційних технологій та проєкт «Країна online. Херсонське дошкілля»; Освіторія «АПгрейд» (для виховате- 
лів); майданчик «СпорТур» (для інструкторів 3 фізичного виховання); майстерня «МайстерМуз» (для музичних керівників); методична лабораторія «Крок» (для вихователів та вихователів-методистів); педагогічний клуб «Майстерня успіху» (для педагогів, які мають педагогічне звання «вихователь-методист» або прагнуть до присвоєння); платформа «Метод» (для вихователів-методистів); наукові студії «Основа» (для педагогів); Освіторія «Хвиля» (зустрічі для керівників та педагогів, у яких є потреба з того чи того питання) тощо.

Висновки. Відповідно до державної освітньої політики, що визначена низкою нормативноправових документів, формуються нові підходи до організації методичної роботи в закладах дошкільної освіти.

Одним зі шляхів реформування першої ланки освіти є якісна організація методичної роботи, що є показником успішності діяльності закладу дошкільної освіти. Методична робота в закладі дошкільної освіти - багатоаспектне поняття, що передбачає: вивчення та моделювання освітнього процесу; супровід професійної компетентності педагогів, підвищення їхньої педагогічної майстерності; вивчення динаміки змін у розвитку дошкільників; консультативну допомогу педагогам; організацію партнерської взаємодії з батьками; вивчення, узагальнення та поширення перспективного педагогічного досвіду; створення сприятливого психологічного клімату в педагогічному колективі; добір та опрацювання методичної, наукової літератури тощо. Тому питання нормативно-правового забезпечення виступає першочерговим в організації методичної роботи в закладі дошкільної освіти. У статті розглянуті основні, на наш погляд, законодавчі, нормативні та відомчі документи, що регламентують процес організації методичної роботи в закладах дошкільної освіти, а саме: Державна національна програма «Освіта» («Україна XXI століття»), Закони України «Про освіту», «Про дошкільну освіту», Наказ «Про затвердження кваліфікаційних характеристик професій (посад) педагогічних та науково-педагогічних працівників навчальних закладів», Примірне положення про методичний кабінет закладу дошкільної освіти, Постанова Кабінету Міністрів України «Деякі питання підвищення кваліфікації педагогічних і науково-педагогічних працівників», Інструктивно-методичні рекомендації «Щодо організації діяльності закладів освіти, що забезпечують здобуття дошкільної освіти у 2019/2020 навчальному році».

Розглянуті законодавчі, нормативні та відомчі документи не вичерпують питання нормативно-правового забезпечення організації методичної роботи в закладі дошкільної освіти. Тому подальше вивчення зазначеної проблематики вважаємо перспективним.

\section{СПИСОК ВИКОРИСТАНИХ ДЖЕРЕЛ}

1. Закон України «Про дошкільну освіту» / Законодавство України. URL: https://zakon.rada.gov.ua/laws/main/ 2628-14 (дата звернення: 14.03.2020).

2. Закон України «Про освіту» / Законодавство України. URL: https://zakon.rada.gov.ua/laws/show/2145-19 (дата звернення: 14.03.2020)

3. Лист Міністерства освіти і науки України «Щодо організації діяльності закладів освіти, що забезпечують здобуття дошкільної освіти у 2019/2020 навчальному році» від 02.07.19 року № 1/9-419 / Міністерство освіти і науки України. URL: https://mon.gov.ua/ua/npa/shodo-organizaciyi-diyalnosti-zakladiv-osviti-sho-zabezpechuyut-zdobuttyadoshkilnoyi-osviti-u-20192020-navchalnomu-roci (дата звернення: 15.03.2020).

4. Наказ Міністерства освіти і науки, молоді та спорту України «Про затвердження кваліфікаційних характеристик професій (посад) педагогічних та науково-педагогічних працівників навчальних закладів» від 01.06.2013 p. № 665. Освіта иа. URL: https://osvita.ua/legislation/other/37302/ (дата звернення: 02.04.2020).

5. Наказ міністерства освіти та науки України «Про затвердження примірного Положення про методичний кабінет закладу дошкільної освіти» від 16.04.2018 p. № 372 / Міністерство освіти і науки України. URL: https://mon.gov.ua/ua/npa/ pro-zatverdzhennya-primirnogo-polozhennya-pro-metodichnij-kabinet-zakladu-doshkilnoyi-osviti (дата звернення: 15.03.2020).

6. Постанова Кабінету Міністрів України : «Деякі питання підвищення кваліфікації педагогічних і науковопедагогічних працівників» від 21 серпня 2019 року № 800 / Законодавство України. URL: https://zakon.rada.gov.ua/ laws/show/800-2019-\%D0\%BF (дата звернення: 15.03.2020).

7. Про Державну національну програму «Освіта» («Україна XXI століття») / Законодавство України. URL: https://zakon.rada.gov.ua/laws/show/896-93-\%D0\%BF (дата звернення: 11.04.2020).

8. Швайка Л. А. Методична робота в ДНЗ. Харків : «Основа», 2017. 304 с.

\section{REFERENCES}

1. Zakon Ukrainy «Pro doshkilnu osvitu». Zakonodavstvo Ukrainy. [Law of Ukraine «On Preschool Education». The legislation of Ukraine]. URL: https://zakon.rada.gov.ua/laws/main/2628-14 (accessed: 03/14/2020). [in Ukrainian].

2. Zakon Ukrainy «Pro osvitu». Zakonodavstvo Ukrainy. [Law of Ukraine «On Education». The legislation of Ukraine]. URL: https://zakon.rada.gov.ua/laws/show/2145-19 (accessed: 03/14/2020). [in Ukrainian]. 
3. Lyst Ministerstva osvity i nauky Ukrainy «Shchodo organizatsii diialnosti zakladiv osvity, shcho zabezpechuiut zdobuttia doshkilnoi osvity u 2019/2020 navchalnomu rotsi» vid 02.07.19 roku № 1/9-419. Ministerstvo osvity i nauky Ukrainy. [Letter from the Ministry of Education and Science of Ukraine «On the organization of activities of educational institutions providing preschool education in the 2019/2020 academic year» dated 02.07.19, Nr 1/9-419 Ministry of Education and Science of Ukraine]. URL: https://mon.gov.ua/en/npa/shodo-organizaciyi-diyalnosti-zakladiv-osviti-sho-zabezpechuyutzdobuttya-doshkilnoyi-osviti-u-20192020-navchalnomu-roci (accessed: 15.03.2020 ). [in Ukrainian].

4. Nakaz Ministerstva osvity i nauky, molodi ta sportu Ukrainy «Pro zatverdzhennia kvalifikatsiinykh kharakterystyk profesii (posad) pedagogichnykh ta naukovo-pedagogichnykh pratsivnykiv navchalnykh zakladiv» vid 01.06.2013 № 665 . Osvita ua. [Order of the Ministry of Education and Science, Youth and Sports of Ukraine «On approval of the qualification characteristics of professions (posts) of pedagogical and scientific-pedagogical employees of educational institutions» of 01.06.2013 Nr 665. Education ua]. URL: https://osvita.ua/legislation/other/37302/ (accessed 02/04/2020). [in Ukrainian].

5. Postanova Kabinetu Ministriv Ukrainy «Deiaki pytannia pidvyshchennia kvalifikatsii pedagogichnykh i naukovopedagogichnykh pratsivnykiv» vid 21 serpnia 2019 roku № 800. Zakonodavstvo Ukrainy. [Resolution of the Cabinet of Ministers of Ukraine «Some issues of professional development of pedagogical and scientific-pedagogical workers» of August 21, $2019 \mathrm{Nr}$ 800. Legislation of Ukraine]. URL: https://zakon.rada.gov.ua/laws/show/800-2019-\%D0\%BF (accessed: 15.03.2020). [in Ukrainian].

6. Nakaz Ministerstva osvity i nauky Ukrainy «Pro zatverdzennia prymirnogo Polozhennia pro metodychnyi kabinet zakladu doshkilnoi osvity» vid 16.04.2018 p. № 372. Ministerstvo osvity i nauky Ukrainy. [Order of the Ministry of Education and Science of Ukraine «On Approval of the Model Regulations on the Methodological Office of the Preschool Educational Institution» $\mathrm{Nr} 1672$ of 16.04.2018. Ministry of Education and Science of Ukraine]. URL: https://mon.gov.ua/en/npa/prozatverdzhennya-primirnogo-polozhennya-pro-metodichnij-kabinet-zakladu-doshkilnoyi-osviti (accessed: 15.03.2020). [in Ukrainian].

7. Pro Derzhavny natsionalnu programu «Osvita» («Ukraina XXI stolittia»). Zakonodavstvo Ukrainy. [About the State National Program «Education» («Ukraine of the 21st Century»). The legislation of Ukraine]. URL: https://zakon.rada.gov.ua/ laws/show/896-93-\%D0\%BF (accessed: 11.04.2020). [in Ukrainian].

8. Shvaika L. A. Metodychna robota v DNZ. [Methodical work in preschool educational institution]. Kharkiv: Osnova, 2017. 304 p. [in Ukrainian]. 